Int. J. Electrochem. Sci., 11 (2016) $4701-4711$

International Journal of

ELECTROCHEMICAL

SCIENCE

WWW.electrochemsci.org

\title{
Effect of the Powder Metallurgy Manufacture Process on the Electrochemical Behaviour of Copper, Nickel and Copper- Nickel Alloys in Hydrochloric Acid
}

\author{
Paula Rojas ${ }^{1, *}$, Rosa Vera ${ }^{2}$, Carola Martínez ${ }^{1}$, María Villarroel $^{2}$ \\ ${ }^{1}$ School of Design, Universidad Adolfo Ibáñez, Diagonal Las Torres 2640, Santiago, Chile \\ ${ }^{2}$ Institute of Chemistry, Faculty of Sciences, Pontificia Universidad Católica de Valparaíso, \\ Av. Universidad 330, Casilla 4059, Curauma, Valparaíso, Chile. \\ *E-mail: paula.rojas.s@uai.cl
}

doi: $10.20964 / 2016.06 .40$

Received: 11 March 2016 / Accepted: 3 April 2016 / Published: 4 May 2016

\begin{abstract}
In this study materials were manufactured using powder metallurgy, by mechanically milling $\mathrm{Cu}$ and $\mathrm{Ni}$ and mechanically alloying $\mathrm{Cu}-\mathrm{Ni}$ (at 50-50 and 60-40\% in weight). In order to consolidate samples at the lowest possible temperature, after the milling cold sintering was used at $300^{\circ} \mathrm{C}$ and $900 \mathrm{MPa}$. This type of sintering does not always give high densities, though it is effective in not significantly altering the characteristics of the materials obtained from the milling process. The microstructural characteristics of the materials were analysed in each phase by X-ray diffraction, spectroscopy and scanning electron microscopy. Considering the sintering conditions and the materials in question, the results show that high densities were achieved (>90\%) with the copper, but the densities were low for the binary alloys and the nickel alone $(<80 \%)$. After the sintering, the electrochemical behaviour of each material was studied in acid media. The results show that under the manufacture conditions of this study, the consolidated 60-40 $\mathrm{Cu}-\mathrm{Ni}$ and $50-50 \mathrm{Cu}-\mathrm{Ni}$ alloys behave better in terms of corrosion in $0.1 \mathrm{M} \mathrm{HCl}$ than the copper and nickel alone.
\end{abstract}

Keywords: corrosion, copper-nickel alloys, polarisation, hydrochloric acid

\section{$\underline{\text { FULL TEXT }}$}

(C) 2016 The Authors. Published by ESG (www.electrochemsci.org). This article is an open access article distributed under the terms and conditions of the Creative Commons Attribution license (http://creativecommons.org/licenses/by/4.0/). 